properties of matter in rarefied gases. These new methods have been applied to industry in a great variety of ways, and in turn have provided the physicist not only with improved forms of apparatus but also with many new technical devices which have made possible still further progress in pure physics. For example, the production on a commercial scale of efficient amplifiers, thyratrons and rectifiers, has provided the physicist with new and powerful weapons for extending his investigations in many directions. These developments have made possible not only the production of streams of swift particles for work on transmutation, but also methods of automatic counting of the swift particles which result from the transformations. These new counting methods owe much to the ingenuity of Dr. Wynn-Williams.
On account of these great improvements in technique and methods, progress in our knowledge has been so accelerated in the last few years that it is not easy for the investigator to keep in close touch with the rapidity of advance of new knowledge.

There have also followed great improvements in the efficient production of X-rays, and I must not omit to mention the development by Coolidge of the hot cathode, highly exhausted X-ray tube, known by his name, which has proved so valuable both for scientific and medical purposes. I could give many other illustrations of the beneficial effects of this close mutual relation between the workers in our university and technical laboratories -a happy relation which cannot fail to be of good augury for the future.

\title{
J. L. Macadam: Father of Modern Road-Making
}

\author{
By Dr. R. Quarendon
}

$T^{\top}$ HE centenary of the death of J. L. Macadam comes at a particularly fitting time, because the history of the roads is passing through a stage very similar to that which marked the years of Macadam's greatest activity. Then, as now, transport was being handicapped by the lack of modern highways, and the march of progress hindered by out-of-date conditions.

The roads were in many cases little better than they had been in the Middle Ages. Two hundred years of neglect, ignorance and prejudice had left them in an appalling state of disrepair. Journeys which now take hours lasted for days or even weeks, and were undertaken only after anxious consideration.

Parliament had done its best to suppress the wheeled vehicle, or to regulate it as a nuisance. Act after Act was passed restricting the loads to be carried, the number of horses per wagon, and the size and shape of the wheels. Excepting the 22,000 miles of turnpikes, the repair of the roads was in the hands of the parishes, who were empowered to conscript labour-known as 'statute labour'-whose services were given with the greatest unwillingness. The 1,100 turnpike trusts were run in many cases by ignorant and incompetent men who took the revenues but spent little on repairs.

Lacking engineering training, Macadam seems to have developed his method from first principles. It was at thirty years of age, after having gained a fortune as an agent for the sale of prizes in the
American War of Independence, that he returned to Scotland to begin his experiments. As magistrate, deputy lieutenant and road trustee for Ayrshire, he was able to give considerable time to this work. His efforts met with the greatest opposition, in spite of the fact that it was his own money which was being spent on the investigation. The Scots people did not want a hard metalled road. They preferred to drive their cattle and geese to market over the soft earth roads which then prevailed.

For many years, Macadam was unable to test his ideas on a suitable scale. In 1798 he was appointed agent for revictualling the $\mathrm{Navy}$ in the western ports, and his duties afforded little time for road research. It was not until 1815, when he became surveyor-general of the Bristol roads, that the opportunity for which he had been waiting arrived.

The usual method of making a road in those days was to dig earth from ditches cut along the side, and to pile it in the middle, in the pious hope that the traffic would beat it into a hard surface. Sometimes gravel was thrown on top, but in wet weather the earth and gravel soon became churned into a pebbly mud. Although he was a pioneer of his day, all Macadam really did was to provide a durable, properly drained bed of road metal. He excavated the earth to a depth of 6-10 inches, according to the nature of the subsoil, and filled in the trench with layers of stone broken to one-inch cubes. The traffic 
was allowed to consolidate the broken stone until it knit together to form a hard smooth surface impervious to water.

Macadam's methods differed from those of his contemporary Telford in two ways. He used no large blocks of stone as a foundation, because he maintained that a soft, elastic base which 'gave' a little would withstand heavy traffic much better. Neither would he have gravel or similar binding material in the surface layer, as Telford recommended.

Many roads which are nowadays described as 'macadam' are not macadam at all, according to the strict letter of the method described by the inventor of the process. They are laid with small material mixed with the larger pieces to act as a binder, a thing which Macadam absolutely forbade. His was a counsel of perfection, however, because unless the stones have the correct shape they will not bed down without admixture to form the regular mosaic characteristic of the true macadam.

Macadam's energy and persistence gradually bore fruit. The enormous improvement of the roads under his jurisdiction became generally known, and in 1823 he described his methods in evidence before a committee of the House of Commons. As a result, macadam replaced the granite causeways in many of London's important streets, in spite of the dismal predictions of people who opposed the change. Southey wrote that "macadamising the streets of London is likely to prove quackadamising", but that opinion was probably due more to his admiration for Telford than to any critical examination of the available facts.

Before recognition came to him, Macadam spent $£ 5,000$ out of his own pocket in developing his method, and travelled 30,000 miles to help officials and others who asked for his advice. The greatly increased speed of the coaches gives a striking proof of the soundness of his ideas, which made English roads the best in the world. Whereas the journey from London to Edinburgh used to take 14-16 days, the time had fallen by 1830 to 40 hours-a remarkable improvement. In recognition of his services, Parliament voted him $£ 10,000$, which he accepted, and he was offered a knighthood, which he declined. His son accepted the honour in his stead.

Macadam described his researches in his memoir : "A Practical Essay on the Scientific Repair and Preservation of Public Roads", published in 1819. Other works on the same subject appeared from his pen. He died on November 26,1836 , in his eightyfirst year at Moffat, near Telford's birthplace, on one of his frequent visits to the scenes of his boyhood.

Although many of Macadam's roads remain, they can no longer compete with the concrete 'speedways' of the modern era. They belong to a quieter age, when the horse jogged leisurely along the country lanes, and the passengers had time to notice the honeysuckle in the hedgerows. Yet they were our roads for more than a century, and it will be many years before the man who made them is forgotten.

\section{Obituary}

Prof. W. A. Parks, F.R.S.

$\mathrm{T}$ HE death occurred in Toronto, on October 3, of Prof. W. A. Parks, professor of geology in the University of Toronto. William Arthur Parks was born in Hamilton, Ontario, in 1868, and educated in Bowmanville High School and the University of Toronto. With his university he was to be associated for the rest of his life, and his career is a long list of ascending responsibilities. He graduated B.A. in 1892 , became a 'fellow of geology' in the following year, and was in turn instructor, lecturer and, in 1905, associate professor. In 1913 he was appointed director of the newly constituted Royal Ontario Museum of Palæontology, an institution which has greatly developed under his guidance. From 1916 until 1922, Dr. Parks was professor of palæontology and in the latter year he was promoted to the full chair of geology.

With his large department and his museum ever increasing in importance, Prof. Parks was fully occupied, yet he found time to conduct expeditions in northern Ontario and to undertake research in various directions. He was particularly interested in American Stromatoporoidea and also published a series of papers on the geology and palæontology of the Toronto distriet. He was also interested in, and published a comprehensive account of, the building and ornamental stones of Canada.

In his later years, attracted by the rich material in his museum, Prof. Parks turned to vertebrate palæontology and described many new genera and species of highly interesting dinosaurs. Despite these numerous activities he found time for service on outside bodies. He was president of Section C (Geology) of the British Association at Southampton in 1925, president of the Royal Society of Canada, 1925-26, president of the Palæontological Society of America, 1926-27, and president of the Royal Canadian Institute, 1928-29. His talents were recognized in Great Britain by his election to the Royal Society in 1934.

For the last few years, Prof. Parks had patiently borne much serious illness, but his interest in his 